\title{
VIEWPOINT
}

\section{Principles and policies for soil and water conservation}

Andrew Manale, Andrew Sharpley, Catherine DeLong, David Speidel, Clark Gantzer, John Peterson, Rex Martin, Clare Lindahl, and Naveen Adusumilli

W e, the Soil and Water Conservation Society ("Society"), maintain that natural resources are a nation's heritage. Soil, water, wildlife, and other ecosystem resources must be protected for future generations. Over decades of research and deliberations of researchers, educators, and practitioners, the Society has identified and developed the following principles for conservation on private lands. This paper is a commentary on working lands for the 2018 Farm Bill and is not meant to be an exhaustive synthesis of all principles held by the Society. Here we describe eight Society principles for soil, water, wildlife, and ecosystem conservation to inform future farm bill discussions and guide development and review of agricultural policies and funding.

\section{PRINCIPLE 1: AGRICULTURAL SOIL, WATER, AND ASSOCIATED WILDLIFE AND ECOSYSTEM RESOURCES MUST BE SUSTAINABLY MANAGED FOR FUTURE GENERATIONS}

In 1946 Hugh Hammond Bennett, the Society's founder, stated, "Productive land, therefore, is our base; for everything we do, all we share, even whatever we amount to

Andrew Manale is a retired US Environmental Protection Agency senior policy analyst, Silver Spring, Maryland. Andrew Sharpley is a distinguished professor in the Department of Crops, Soils, and Environmental Sciences, University of Arkansas, Fayetteville, Arkansas. Catherine DeLong is special projects director for the Soil and Water Conservation Society (SWCS), Ankeny, lowa. David Speidel is a retired agriculture advisor/district conservationist, USDA Foreign Agricultural Service/Natural Resources Conservation Service, Benton, Missouri. Clark Gantzer is an emeritus professor of the University of Missouri-Columbia, Columbia, Missouri. John Peterson is the SWCS Washington, DC, representative, Burke, Virginia. Rex Martin is chief executive officer of Alpha Gamma Rho Fraternity, Kansas City, Missouri. Clare Lindahl is executive director of SWCS, Ankeny, lowa. Naveen Adusumilli is an assistant professor and extension economist in the Department of Agricultural Economics and Agribusiness, Louisiana State University, Baton Rouge, Louisiana. as a great people, begins with and rests on the sustained productivity of our agricultural lands" (Bennett 1946). Agricultural lands provide food, fiber, and fuel, and if managed with regard to their environmental and social impact, can provide services, such as wildlife and pollinator habitat, clean water, clean air, flood and drought mitigation, and recreational opportunities. Healthy soils enable production of agricultural goods, filter water, sequester carbon (C) and nitrogen (N), and offset release of greenhouse gases.

Agricultural land must be managed to ensure positive value for both products and services. Clean water is a shared and cooperatively managed resource, and agricultural land should be managed so as not to jeopardize this public good. Managing land for ecosystem services protects the integrity of agricultural lands and promotes the land ethic expressed by Aldo Leopold, which "enlarges the boundaries of the community to include soils, waters, plants, and animals, or collectively: the land" (Leopold 1949). However, not all ecosystem services generate marketplace value. For these, their social and environmental value must be inferred through consideration of public and long-term ecological benefits.

Implications for Policy. Public funding is necessary to support conservation programs and research to protect services and their foundational resources that private markets undervalue. Institutional support is necessary for ensuring proper social valuation. The concept of ecosystem services provides the best framework for understanding human needs and their reliance on the ethical, holistic management of land and resources to serve these needs.

\section{PRINCIPLE 2: SUSTAINABLE STEWARDSHIP OF AGRICULTURAL LANDS DEPENDS UPON SCIENTIFICALLY SOUND RESEARCH AND EFFECTIVE COMMUNICATION}

Long-term research, data collection, and data availability are essential to the sustainable management of agricultural lands, which are likely to transform with climate change and societal pressures. Publicly funded research is necessary to provide this information to all farmers, practitioners, and the public. Education and Conservation Technical Assistance are essential to promote adoption of conservation practices by farmers and ranchers (SWCS 2011).As Ralph H. Musser (1946), the first president of the Soil and Water Conservation Society, stated, "At the core this great endeavor to hold onto the world's store of productive soil and water, will be the professional soil conservationist."

Implications for Policy. Agricultural research should be funded at levels sufficient to meet the needs of sustainable stewardship of agricultural lands and resources. Research priorities should reflect the need to protect resource resilience in light of changing climatic conditions. Public funds should leverage private resources to increase funding. Conservation Technical Assistance ("boots on the ground") is the main delivery system of conservation knowledge to farmers and ranchers, and this role must be safeguarded through public funding.

\section{PRINCIPLE 3: HEALTHY SOILS ARE}

PRODUCTIVE AND RESILIENT SOILS

Soil organic matter is an essential component of healthy soils. Soil organic matter helps retain soil moisture, sequester $\mathrm{N}$, enhance water conservation, and is as a major sink for greenhouse gases. Maintaining or increasing organic matter levels in agricultural soils, including grazing and pasturelands, must be a goal of farm policy. Healthy soils, because of their enhanced soil structure and increased infiltration capacity, are less vulnerable to erosion and nutrient loss that can pollute water resources. Improved cropping, fertilization, and management, including reduced tillage, crop rotation, cover crops, and sustainable grazing practices, are important to maintaining and achieving healthy soils.

Surface and subsurface drainage should be managed to minimize water and nutri- 
ent loss. Although conservation practices are implemented and managed at field and farm scales, their benefits are better captured at landscape or watershed scales. Public investment is needed to support the development of tools for identifying and guiding conservation planning, such as watershed planning, and, importantly, the continuing education and training of people who will provide and use those tools.

Implications for Policy. Government and private sectors must maintain incentives to manage soils for organic matter content and, where necessary, maintain or promote incentives for soil and water conservation. Policies, such as the Conservation Compliance, Wetlands Conservation Provisions (Swampbuster), Sodbuster, and Sodsaver, must be maintained or enhanced, where necessary, to encourage stewardship. Agricultural policy should encourage reduced tillage, sustainable crop rotations, cover crops, C sequestration, sustainable grazing, and drainage management. Conservation programs should help the public and private sectors acknowledge and reward good stewardship through payments for conservation performance.

Innovative market mechanisms should be explored where the beneficiaries of sustainably managed agriculture contribute directly to support these services, thus supplementing public funding. Policies should support markets in livestock manure to ensure its appropriate use on a watershed or regional basis. Crop subsidies, crop insurance, and income support programs should require stewardship of natural resources and protection of environmental quality, such as through the Conservation Compliance Program. Although financial and educational support occurs at the farm level, planning and program implementation should encompass watershed and landscape scales for greater effectiveness. Timely assessment should guide program adjustments; understanding of soil health will be gained, thus leading to more effective practices for improving soil health and water quality.

\section{PRINCIPLE 4: WETLANDS AND FLOODPLAINS ARE ESSENTIAL TO LONG- TERM RESOURCE SUSTAINABILITY}

Wetlands are necessary for managing excess farm nutrients, receiving, and managing water in high rainfall events, adapting to drought conditions, and for healthy wildlife populations. Many, if not most, are irreplaceable. Mitigation banking can be a useful tool for maintaining and enhancing values and functions of wetlands in situations where wetlands and high-value farming are in conflict. Mitigation banking can be effective if “(a) banks are used strictly to mitigate unavoidable wetland impacts or losses, (b) impacts are mitigated on-site where possible, (c) banks are located in the same watershed or ecological region as the wetland impacts they mitigate, and (d) banks provide in-kind replacement of wetland functions and values lost" (US House of Representatives 1994)

Floodplains represent special ecosystems of particular importance to the well-being of many communities. They serve numerous competing uses from transportation, urban development, human and industrial water consumption, agriculture, recreation, and wildlife habitat. Knowledge of river systems' presses and pulses is necessary to manage floodplain resources. Special consideration must be made to maintaining connectivity to river systems to mitigate the impacts of floods and droughts on these competing uses. Farmed floodplains, when managed sustainably, can store potential floodwaters, provide recreational benefits, and serve as habitat for wildlife.

Implications for Policy. Agricultural policy should discourage the conversion and poor management of wetlands, both perennial and seasonal, and encourage maintenance and enhancement of their functions and values. Current farm bill programs, such as Swampbuster, Wetland Mitigation Banking, the Conservation Reserve Program (CRP), and the Agricultural Conservation Easement Program (ACEP) should be reauthorized and supported.

Further, agricultural policy in farm bills should make clear the preferential management of floodplains for ecosystem services, such as flood mitigation. Water quality monitoring should also be considered to assess practice effectiveness.

\section{PRINCIPLE 5: FARM BILLS SHOULD INCENTIVIZE FARMERS AND UTILITIES TO WORK TOGETHER TO PROTECT DRINKING WATER}

All communities should have access to safe and plentiful drinking water, or source water. Rural communities are at greater risk to drinking water contamination, according to the Center for Disease Control and Prevention (2017). Yet, these communities are often unable to take on costly utility and infrastructure upgrades (Strosnider et al. 2017). In order to protect rural and urban source water, farmers should be incentivized to target conservation practices on land that surrounds and impacts critical drinking water sources.

Implications for Policy. Conservation title funding in farm bills should encourage water utilities and farmers to partner through the Environmental Quality Incentives Program (EQIP), Conservation Stewardship Program (CSP), ACEP, and Regional Conservation Partnership Program (RCPP). Funding sources such as the Water Infrastructure Finance and Innovation Act (WIFIA) and state revolving loan funds, which allow utilities to leverage infrastructure upgrades to support upstream conservation, should receive robust funding. Farmers should be incentivized to target their conservation practices to areas with the greatest potential to positively impact drinking water sources.

\section{PRINCIPLE 6: CONSERVATION OF AGRICULTURAL LANDS AND AGROFORESTRY SHOULD NOT CONFLICT WITH WILDLIFE CONSERVATION}

Wildlife, especially pollinators, are essential for healthy ecosystems. The public's support of agricultural funding will be enhanced through understanding the potential for agricultural land to act as habitat for pollinators and wildlife. Moreover, the provision of wildlife coupled with its many benefits, represents an important ecosystem service that can be a significant source of revenue for landowners and farmers.

Soils need to be managed for sufficient protective plant residue cover to mini- 
mize soil organic matter loss, erosion, loss of moisture, and resilience to extreme weather events. In addition to commodity crops, such as corn (Zea mays), soybeans (Glycine max), wheat (Triticum aestivum), and cotton (Gossypium hirsutum), which are vital components of the rural economy, "perennial species, incorporated into diverse agricultural systems, have great potential to enhance resilience against uncertain climate and market conditions" (Steiner et al. 2009). Through the development of on-farm and rural enterprises that utilize agroforestry and horticulture, agriculture can help revitalize communities and provide healthy, locally sourced food options (Steiner et al. 2009).

Agroforestry and perennial vegetation practices, such as windbreaks and riparian buffers, can reduce erosion impacts and sequester $\mathrm{C}$ through enhanced root development, and aboveground vegetation serves as biofuel feedstock. Agroforestry can provide wildlife habitat and pollination services, and provide for the temporary storage of water, mitigating the magnitude of flooding.

Implications for Policy. The current relative importance of wildlife habitat in the ranking of conservation funding priorities should be maintained. Existing limits on CRP acreage should be raised to a level consistent with the needs of restoring critical wildlife habitat, to reflect public support for environmental amenities, and to achieve resilience in a changing climate. To achieve the same benefits, ACEP should be maintained, with adjustments to its program objectives to encourage participation across a wider public sector. Agricultural conservation policy should explicitly acknowledge the importance of agroforestry in protecting the integrity of ecosystems and conservation programs.

\section{PRINCIPLE 7: AN INFORMED PUBLIC IS NECESSARY FOR SUSTAINABLE MANAGEMENT OF SOIL, WATER, AND ASSOCIATED WILDLIFE AND ECOSYSTEM RESOURCES}

All people need to understand and recognize the potential role of agricultural lands to provide ecosystem services, such as healthy soils, water quality, flood protection, wildlife and pollination habitat, recreation, and aesthetic amenities. The public, as consumers of food, fiber, and fuel, needs to understand how agricultural goods are produced, how well-being relates to agriculture, and the public sector's role in ensuring high-quality products and services. Continued funding for conservation research and implementation depends upon public awareness of the benefits of soil and water conservation (SWCS 2011). An informed public will understand that healthy soil can serve as a sink for $\mathrm{C}, \mathrm{N}$, and water; thus mitigating the impacts of extreme weather events. Soil and water conservation practices can alleviate the effects of changing seasonal temperature and precipitation regimes on soils, plants, and animals. Education on soil health and water quality can help farmers and ranchers, scientists, and conservation practitioners exchange information and gain experience that improves the application and adoption of conservation systems (SWCS 2011).

Implications for Policy. Farm bills should continue to support educational activities associated with sustainable agriculture through institutional support and funding. There should be adequate funding for economic and public policy analyses to valuate and convey the benefits of well-managed agricultural systems, to identify opportunities for developing partnerships with the public and private sectors, and to facilitate ecosystem service markets. Policy should encourage government, private, and nonprofit stakeholders to "coordinate efforts to communicate the relationship of soil and water conservation practices, climate change mitigation and adaptation, and food security" and to share critical information (SWCS 2011).

\section{PRINCIPLE 8: RESPONSIBLE CONSERVATION MANAGEMENT DEMANDS ACCOUNTABILITY}

The public has the right to know how funds are spent and what they have accomplished. Accountability in agricultural conservation means collecting the right information on what the effort has achieved (monitoring), comparing the effects to established environmental goals that are linked to the ecological and eco- nomic context in which the interventions occur (evaluation), and placing appropriate practices to address a concern (targeting) (SWCS 2006).

Model simulations, while powerful tools for estimating relative qualitative comparisons of varied conservation strategies, "cannot - and must not-substitute for on-the-ground monitoring and inventory systems designed to determine if anticipated conservation and environmental benefits are being achieved" (SWCS 2006). People must manage these lands to ensure their future productivity and to protect them from degradation by a changing environment. Adaptive management can be an effective tool supporting agricultural conservation efforts. The principle of adaptive management requires that interventions be continuously assessed and refined to achieve maximum efficiency. In adaptive management, monitoring and assessment are built into the planning and implementation process and funding should reflect associated costs. Benchmark measures should encompass not just project sites but larger landscape and ecological processes that are linked. The results of monitoring and assessment are used to make timely adjustments in management decisions in order to improve outcomes.

Implications for Policy. Government should fund watershed planning and programs, which are jointly managed at federal and state levels and which provide for targeting, monitoring, and assessment necessary to achieve measurable results. These programs should be incorporated, where practical, into conservation projects to ensure effective outcomes and avoid waste and mismanagement. Ideally, use of monitoring/assessments should become the norm in selecting and continuing watershed-scale projects and in determining the level of annual expenditures.

Public policy should "ensure a longterm commitment of people and resources to community-driven projects at the watershed scale," as "the more traditional approach of providing short-term, three- to five-year grants to communities will not work" (SWCS 2007). To this end, soil and water conservation districts; watershed boards; and local, state, and federal agencies have a responsibility to 
make the best use of current and emerging practices. The use of monitoring assessments should become the norm in selecting and continuing watershed-scale projects and in developing the level of annual expenditures.

\section{CONCLUSIONS}

The eight conservation principles described here, are proposed as a framework to ensure continued development of science-based strategies that protect soil, water, and ecosystem resources. These principles also serve as guides to inform future state and federal conservation policies, support, and farm bill discussions.

\section{ACKNOWLEDGEMENT}

The authors wish to acknowledge the contributions of the members of the Soil and Water Conservation Society Science and Policy Committee, who reviewed and commented on multiple drafts of these principles.

\section{REFERENCES}

Bennett, H.H. 1946. A national program of soil conservation. Journal of Soil and Water Conservation 1(1):21-34.

Center for Disease Control and Prevention. 2017. Rural Americans at higher risk of death from five leading causes. https://www.cdc.gov/media/ releases/2017/p0112-rural-death-risk.html.

Leopold, A. 1949. A Sand County Almanac and Sketches Here and There. New York: Oxford University Press.

Musser, R.H. 1946. Why another society? Journal of Soil and Water Conservation 1(1):3-4.

Steiner, J.L., A.J. Franzluebbers, and C.L. Neely. 2009. Expanding horizons of farming with grass. In Farming with Grass: Achieving Sustainable Mixed Agricultural Landscapes, ed. A.J. Franzluebbers, p. 216-234. Ankeny, IA: Soil and Water Conservation Society. https:// www.swcs.org/resources/publications/books/ farming-with-grass-online.

Strosnider, H., C. Kennedy, M. Monti, and F. Yip. 2017. Rural and urban differences in air quality, 2008-2012, and community drinking water quality, 2010-2015-United States. Morbidity and Mortality Weekly Report, Surveillance Summaries 66(13):1-10, doi:10.15585/mmwr. ss6613a1.

SWCS (Soil and Water Conservation Society). 2006 Final Report from the Blue Ribbon Panel Conducting an External Review of the US Department of Agriculture Conservation Effects Assessment Project. Ankeny, IA: Soil and Water Conservation Society.

SWCS. 2007. Planning for Extremes. Ankeny, IA: Soil and Water Conservation Society.

SWCS. 2011. Position Statement of Climate Change and Soil and Water Conservation. Ankeny, IA Soil and Water Conservation Society.

US House of Representatives. 1994. Committee on Agriculture, Subcommittee on Environment, Credit, and Rural Development. Review the Impact of Wetlands and Nonpoint Source Pollution Regulations on Agricultural Land. 103rd Congress, 2nd session, March 23. Serial No. 103-61. Washington, DC: US Government Printing Office. https://ia902608.us.archive. org/33/items/reviewimpactofwe00unit/ reviewimpactofwe00unit.pdf?. 